\title{
放射線がん治療における精密技術* \\ Precision Technology in the Radiation Therapy
}

\section{尾木靖夫** \\ Yasuo OGI}

\section{1. は じめ に}

近年の少子高齢化社会の急速な進展およびがん患者の急 増にともない, 非侵襲的な治療法の一つである放射線治療 の重要性が急速に高まっている。単に治療して治ればよい という治療から，治療と同時に患者が充実感や満足感をも って日常生活を送ることを重視する, いわゆる QOL (Quality of Life) の向上が求められている.

がんの放射線治療は, 外科的手術, 抗がん剂による化学 療法とともにがん治療の 3 つの大きな柱の一つであり, 医 療現場・企業等の絶え間ない努力により，近年ではより患 者に負担が少なく治療効果も部位によっては手術と肩を並 心゙る治療法（体幹部定位治療, 強度変調放射線治療 (Intensity modulated radiation therapy;IMRT)) 等 が 次々と開発された。これにより, 体力の劣る高齢ながん患 者が増えていく中で, 放射線治療の重要性が今まで以上に 増すと思われる。

本稿では，放射線治療の技術革新，特に近年発展の著し い高精度放射線治療の技術動向について解説する。さら に，放射線治療の発展を目指し開発した高精度画像誘導型 放射線治療装置の特長について紹介する。

\section{2. 放射線治療の技術革新}

外照射放射線治療は, 大まかには, X 線や $\gamma$ 線等の光子 (電磁波) を用いる光子線治療と, 電子のような軽粒子, 陽子や中性子等の中間的な質量の粒子, ホウ素や炭素等の 重粒子を加速して用いる粒子線治療に分類される.

陽子線や炭素イオン等の重荷電粒子線では, 高エネルギ 一に加速された場合, 体内でのその直線的な飛程の最後で 急激な電離を発生する現象（ブラッグ・ピーク ${ }^{1)}$ ) があ り, 荷電粒子線の加速エネルギーにより深度方向の線量分 布の制御が可能である。粒子線を，治療に適した高エネル ギーに加速するためのサイクロトロンやシンクロトロン加

*原稿受付 平成 25 年 12 月 23 日

**三菱重工業株式会社機械・鉄構事業本部先端機器事業推進部（東京都港区 港南二丁目 16 番 5 号)
速器はいずれも物理実験用の巨大装置であり, 臨床普及に は多くの問題がある.

医療用電子リニアックは, 米国および英国を中心に開発 が進められ，1980年代初頭には加速器技術としてはほぼ 完成の域に達しているが, 高精度放射線治療の観点から は, 自由度の高い線量分布の形成, 高精度照準という問題 を解決する必要があり, IMRT, IGRT（画像誘導放射線 治療；Image-guided Radiation Therapy）および動体追尾 照射治療が光子線治療の将来技術として開発されつつ ある。

IMRT は, 治療計画ソフトウェアを用いて, 必要とな る線量分布を実現する MLC（Multi-leaf Collimator）のリ ーフのパターンを逆解析的に求めて, 電子リニアックを制 御するものであり，1990 年代初頭から開発が始まり，一 般の医療用電子リニアックに付加する方式や，特色をもっ た専用装置で普及しつつある。特に，放射線耐性が低く， また穴長性のない健常組織は危険臓器 (OAR: Organ At Risk）と呼ばれ，許容できない副作用のために，治療部位 への線量投与を制約し, 放射線治療の信頼性を劣化させる 主な要因となっている。

MLCを用いた原体照射（Conformal Radio Therapy）で も実現できない線量分布の一つとして凹型形状がある。こ れは，照射野が凹型になっておりこれに隣接して OARが 存在する場合に必要となる。放射線治療医の約 30\% はこ のような凹形状の線量分布を必須と考えているといわれて おり，これにより，手術に匹敵する治療効果も期待できる 「高精度放射線治療」への扉が開かれたといっても過言で はない。

IMRTによる凹型の線量分布の形成の原理図を図 1 に 示す。各門を複数のセグメントに分割し，各セグメントご とにMLCでビーム形状を成形して, 各門からの照射に対 して二次元の線量分布を与え, 全門からの照射を合成する ことにより，立体的な凹型形状の線量分布を形成すること が可能となる.

さらに最近では, ガントリーを回転させながら次々に MLC 形状を変更して，任意の線量分布を立体的に形成す 
1. 各門を複数のセグメントに分割.

2. 各セグメントごとに MLCでビーム形状を制御して 照射し, 各門からの照射線に二次元の線量分布を 与える。

3，全門を合成することにより，立体的な凹型形状 分布の線量分布を得る。

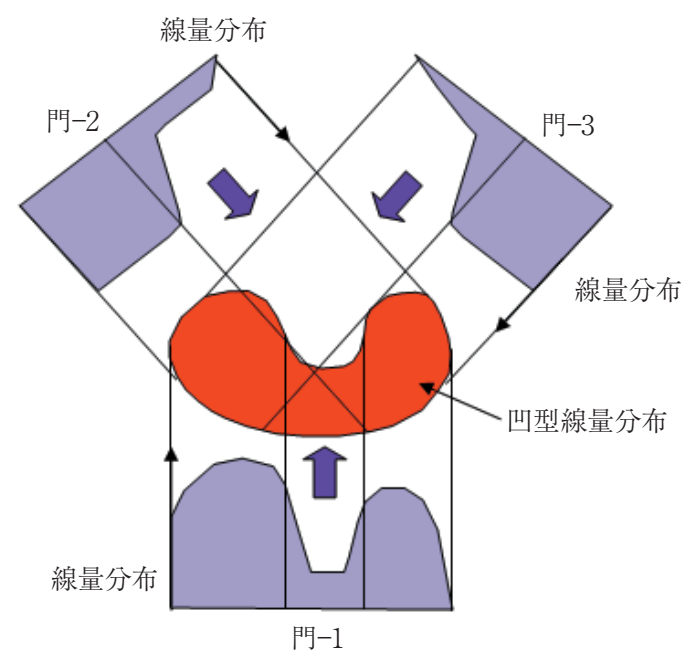

図 1 IMRT による凹型線量分布形成

るVMAT（Volumetric Modulated Arc Therapy）を行う 治療装置も出現している.

IMRT とほぼ同時並行に開発が進められてきたのが, 画像誘導放射線治療技術（IGRT）である。

従来の照準は, 患者の皮膚上につけたマーカをレーザ 一・ポインタで狙って位置合わせを行い, 従来型の医療用 電子リニアックがその機能の一部としてもっている光学照 射野を，患者の皮膚に投影して皮膚上で患者の体位やアイ ソセンタの確認を行って照準する方式であった。皮膚上の マーカと実際の体内の目標位置の一致度には問題があり, 大きな照準誤差や照準の不確定性の原因となっていた。こ のため，高い照準精度が要求される場合には，ビーム・ス トッパー部に X 線フィルムを置いて患者の体の透過像を 撮像するリニアック・グラフィにより，治療台上に患者を セットアップした状態で患者の骨構造を撮影して, 位置決 めをすることが行われてきた. 1990 年に電子リニアック の付加物として EPID (Electronic Portal Imaging Device) が開発された。これは，ビーム・ストッパーの部分に 2 次 元のマトリクス状の検出器を置き，患者の体を透過してき た治療 X 線のイメージングを行うものである。EPIDを用 いることで, 従来のリニアック・グラフィを用いた方法の ような手間をかけずに迅速な位置決めが可能となる。

その後, 診断用の X 線 CT と医療用電子リニアックを 同室に設置し, 治療用のカウチを挟んで対向するように配 置して，患者をカウチ上で治療状態にした上でターゲット を X 線 CT で確認し，その照準位置を電子リニアックの 方に移して治療照射を行う装置が開発された。ただし，力 ウチの移動に起因する誤差は排除できず，また，いったん X 線 CT でターゲット位置を確認した上で，再度，術者が 治療室に入ってカウチのセットアップ等を実施する必要が
あり，治療効率の点で問題があった。

そういった問題を解消することを目的とし，ガントリー 上に装備された $\mathrm{kV} \mathrm{X}$ 線ラジオグラフィ装置をガントリー とともに回転させて CT データを取得し, 再構成して CT 画像を得る方式が開発されている。

照準誤差の要因として上記に加えて重要なものは, 患者 の体動によるものである，体位，体位置の変化はもちろん のこと, 消化管内のガスや内容物, 膀胱内の尿量の変化, 呼吸や心拍により，患部の位置は変化する。肺野の腫瘍に ついては, 周波数が約 $0.3 \mathrm{~Hz}$ 程度で最大 $4 \mathrm{~cm}$ 程度の呼吸 性移動がある。呼吸動の臨床的な取り扱いについては，振 幅が $5 \mathrm{~mm}$ を超え患者の容態が許容するならば何らかのマ ネジメントを実施すべきであるとされている。マネジメン トの方法としては，息止めや圧迫等による体動の抑制が最 も原始的なものであるが, 患者の容態により受け入れられ ない場合が多い, 患者の負担を軽減するため, 患部の運動 をステレオ方式の X 線ラジオグラフィや胸部マーカ等の 代理信号（Surrogate）で追尾し, 治療装置の照準内に入 った場合のみ治療線を照射する呼吸ゲート方式が開発 ${ }^{2)}$ れているが，照準精度を上げようとすれば，治療時間が増 加して患者の負担が増加するとともに，X線ラジオグラ フィで追尾する場合には，長時間のモ二夕線被爆の問題も 深刻化する。上記の問題を解決するためには，治療線を患 部の移動に追尾させて照準する, 動体追尾照射治療が重要 になる ${ }^{3)}$.

\section{3. 高精度放射線治療機の開発}

\section{1 開発目標}

放射線治療の最新技術である IMRT, IGRT を可能にす るだけでなく，真の高精度治療を行う上での課題の対処， 動くがんに対する対応, 複雑化する放射線治療装置を容易 に使える操作環境や自動 $\mathrm{QA}$ 機能，等を実現するために， 以下の設計指針を設定し，開発を行った。

1）真の高精度を実現すること。

・ビーム照射および画像取得の機器全てが高精度で あること、

・ノンコプラナー照射時でも, ビーム照射精度を確 保できること.

2）人間を強固に固定する思想ではなく, 動く人間に合 わせて機械が動くようにすること（動くがんについ ても高精度治療を実現する機能を有すること)。

3）統合した使いやすい操作環境を提供すること（自動 QA も含む) .

\section{2 装置構成および特長}

上記設計指針にて開発した放射線治療装置は，X線撮 影と治療を融合させた画像誘導高精度放射線治療（IGRT） を実現する装置である。装置の外観図を図 2 に示す。

その本体には，工作機械で要求される微小位置決め技術 や印刷機械で培った画像処理技術，製鉄機械分野の制御技 術や大型加速器の製造開発などの知見を最大限に反映した 


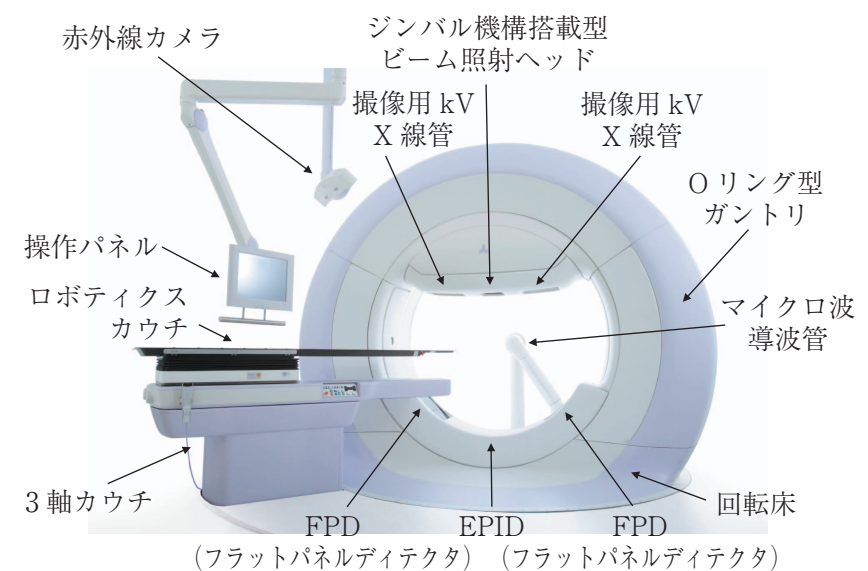

図 2 MHI Vero4DRT の外観図

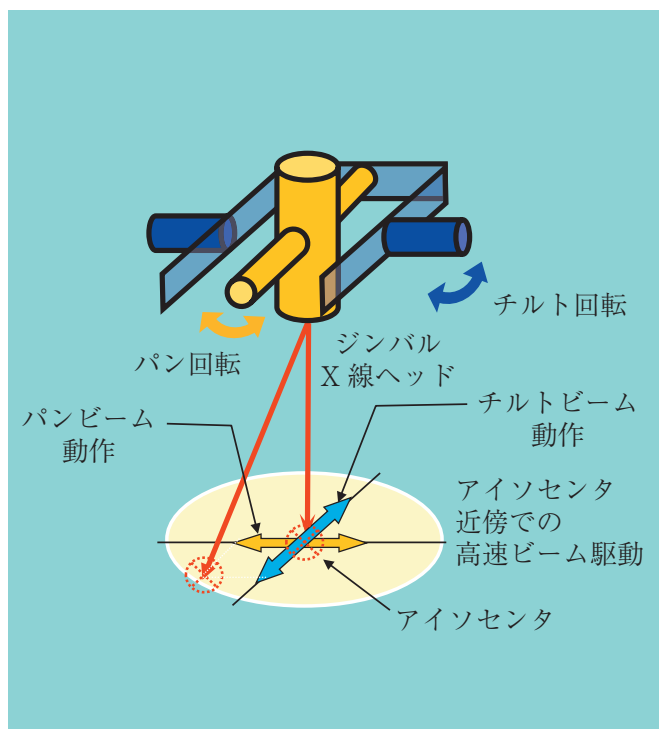

図 3 ジンバル機構模式図

構造を採用している ${ }^{4) 5)}$.

（1）ジンバル支持 X 線ヘッド方式

本装置には，治療線を体動に追尾させて高速に移動する ために，図３に示す「ジンバル支持 X 線へッド方式」を 考案し導入した， X 線ヘッドは，その重心位置でパンお よびチルト軸の 2 軸のジンバル上に支持されている。ジン バル軸からアイソセン夕までの距離は約 $1 \mathrm{~m}$ であり, 土2.5のジンバル軸の回転により，アイソセンタを中心と

して 1 辺が $80 \mathrm{~mm}$ の正方形の範囲内を任意の位置に高速 に照準可能である.

(2) O-ring の構造と性能

ジンバルは, 図 4 に示すように高剛性の O-ring 構造で 支持されている。-ring は，システムのアイソセンタを 中心に $360^{\circ}$ 回転して照射門を設定するほか, カウチと接 触しない範囲でその鉛直軸の周囲でスキュー旋回して，患 者の体軸に対して傾斜した方向からの治療線の照射（ノン コプラナー照射）を可能とする。O-ring 自体は極めて高 い剛性を有しており，X線へッドの位置による機械的な たわみはごくわずかであるが，これをさらにジンバル軸の

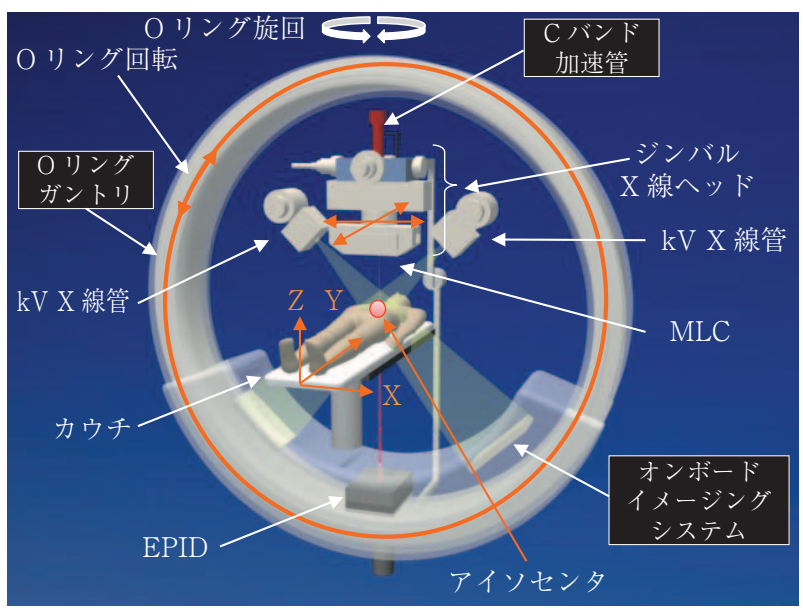

図 4 MHI Vero4DRT の構造概要図
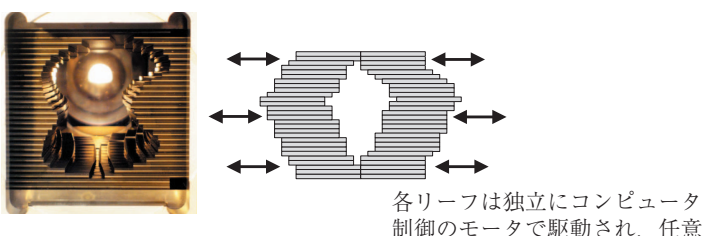
制御のモータで駆動され，任意

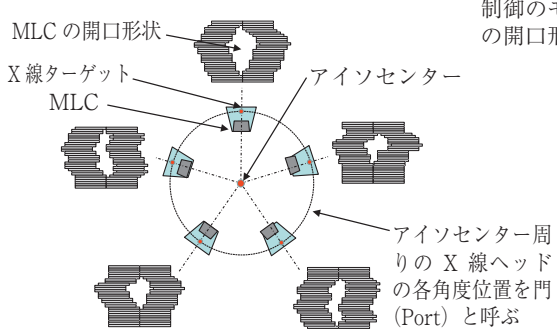

各門で MLC の開口形状 を制御して照射する 各門から見た目標形状 (BEV : Beams Eye View）に合わせて MLC の開口を照射する方法 を CRT (Conformal Radiation Therapy) $と$

図 5 MLC の概要説明図

回転で補正して，アイソセンタにおいて $\pm 0.1 \mathrm{~mm}$ という 極めて高い照準精度を実現している。O-ring上には，2 組の $\mathrm{kVX}$ 線管球とアイソセン夕を挟んで, これらと対向 するように置かれたフラットパネルディテクタ（FPD） から構成されるイメージングサブシステムが装備されてい る。また，X線へッドとアイソセン夕を挟んで，これら と対向する位置には, EPIDを備えて, 治療線による照射 画像のモニタを可能としている.

（3）X線ヘッドの構造と性能

X 線へッドには, アイソセンタにおいて幅 $5 \mathrm{~mm}$ のリー フを片側 30 枚対でもつマルチリーフコリメータ（MLC ; 図 5 参照）を装備しIMRTを可能としている.

$\mathrm{X}$ 線のエネルギーとしては, 脳, 頭頸部, 肺野などの 治療に最適な $6 \mathrm{MV}$ を選定したが, IMRTを前提とすれ ば，前立腺などの深部の治療にも臨床上問題なく適用でき ることが報告されている ${ }^{6)}$ 。また最大照射野は，前立腺等 の体幹部治療も考慮して $15 \mathrm{~cm} \times 15 \mathrm{~cm}$ とし, 定位治療時 の大線量照射時の照射時間の短縮のため, 線量率としては $500 \mathrm{cGy} / \mathrm{min}$ (ピーク深において）とした.

図 6 にX 線へッドの概要図を示す。加速管の全長は電 子銃まで含めて約 $40 \mathrm{~cm}$ とコンパクトである. 動体追尾 


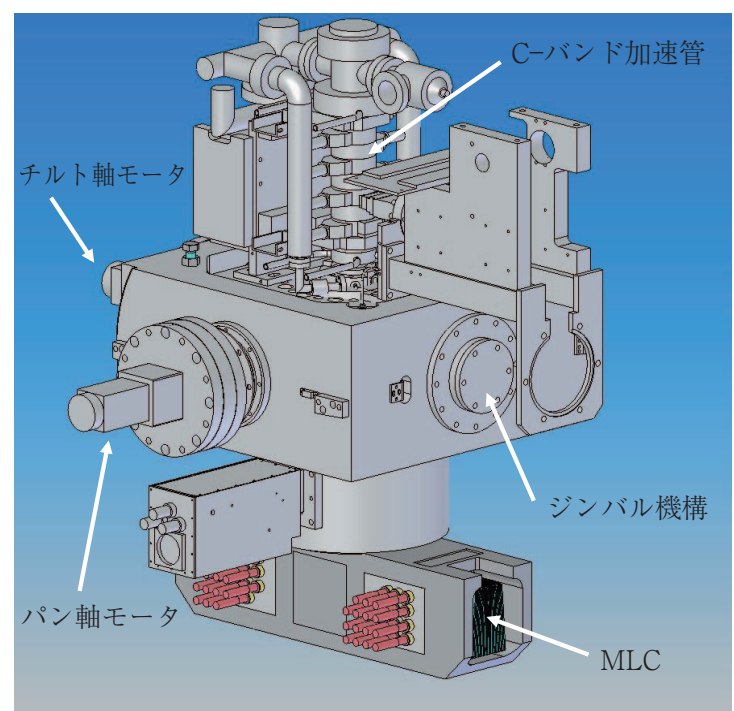

図 6 X 線ヘッド概要図

照射治療に必要なジンバル角速度の実現のため, X 線へ ッドの重量は極力軽く, 軸周りの慣性モーメントも極力小 さくする必要がある。このため, 新規開発のCバンドの 超小型・軽量の加速管を採用し, 加速管自体の軽量化を徹 底した。

イメージングサブシステムは，腫瘍やマーカーを追跡し 動体追尾照射治療を可能とするとともに, 治療計画時の X 線 CT 画像から再構成した画像との自動照合を行って, 骨構造基準の IGRT が実施できる。また，O-ring 回転に より取得したコンビーム CT (CBCT) 画像を, 治療計画 時に取得した X 線 CT 画像との自動照合を行うことも可 能である

（4）システム性能の評価

治療線の照準精度評価の一環として, Star Shot 法によ り集光特性を評価した。 X 線フィルムを,アイソセン夕 軸に直交する平面に置き, MLCで形成した細いリボン状 のビームで O-ring の回転角度を $30^{\circ}$ 刻みで変化させなが ら曝写し，X線フィルム上の集光度を評価した結果，最 大 $0.04 \mathrm{~mm}$, 平均で $0.018 \mathrm{~mm}$ の極めて良好な集光特性が 得られた。

動体追尾治療に必要なジンバル追従精度についても, 呼 吸性移動を模擬した $0.75 \mathrm{~Hz}, 20 \mathrm{~mm}$ 振幅の正弦波入力に 対しては誤差 $0.6 \mathrm{~mm}$ 以内, 一方，拍動を模擬した 2.0 $\mathrm{Hz}, 4 \mathrm{~mm}$ 振幅の正弦波入力に対しては誤差 $0.4 \mathrm{~mm}$ 以内 が達成できており，十分な追従性が確保できている。

\section{4. 動体追尾照射治療の実現}

動く腫瘍に対し，従来は「腫瘍が動く範囲全体を広めに 照射する」「動く腫瘍がビームに入る位置に戻ってきたと きのみ照射する」等の照射技法で治療を行っている。しか し，前者は腫瘍以外の正常な組織への照射が増え，後者は 治療時間がかかる等の問題がある。

本装置は, 2 対の $\mathrm{kV} \mathrm{X}$ 線撮像システムとジンバル機構
を活用し，動く腫瘍に短い治療時間で照射する動体追尾照 射が可能である。動体追尾照射は，治療中に次のステップ で照射を行う（図 7)

(1) 呼吸に応じて動く腫瘍の 3 次元位置を連続的に認識 する.

(2) ジンバル機構により, 治療用 X 線の照射方向を腫瘍 位置に連続的に追従させる。

(3) 治療用 X 線の照射量が所定の量となるまで連続的に 照射を行う。

今回搭載した「金マーカ併用型呼吸信号追尾方式」は, 前述11において認識しにくい（見えにくい）腫瘍近傍に指 標となる金マーカを留置することで，より安定して腫瘍を 認識する技術を採用した。これにより，腫瘍の見えやすさ に関わらず，自動的に金マーカを安定検出するため，ロバ ストな追尾照射が可能となった。 なお，ここで用いる金マ 一カは, 直径 $1.5 \mathrm{~mm}$ 程度であり腫瘍近傍の気管支に非切 開で扦入することが可能で，患者の肉体的負担は手術など に比べて小さい

また，胸部・腹部の上下動などの呼吸信号と，呼吸によ る腫瘍の位置に高い相関性があることを利用して，体内の 腫瘍位置を推定する技術を採用した。これにより，二方向 から連続的に画像取得用 X 線を照射しながら追尾する方 式に比べ, X 線撮像回数を減らせるため不要な被爆の大 幅削減に成功した。 この結果, 本方式では動体追尾の線量 集中性のメリットは確保しつつ，同時により患者に優しい 治療を実現し，2011年より本格的な動体追尾治療を開始 している.

さらに, 動体追尾機能に強度変調放射線治療（IMRT） を融合したリアルタイムモニタリングによる動体追尾 IMRT 治療を 2013 年に世界で初めて実施した. IMRT は，前述のとおりがん病巣への集中的な放射線照射を実現 した革新的な治療法である。一方，呼吸により摇れ動く臓 器に対しては, 高い照射精度を要求するIMRTのような 照射技法を併用することは容易ではなかった。 IMRTに 動体追尾治療を融合させることで, 呼吸により病巣が移動 する膵蔵がんに対し, 治療中も自由に呼吸ができる患者に 優しい治療が可能となった。

\section{5. 放射線治療機の評価}

放射線治療機において, 正確な照射精度をいかに確保す るかという課題は, IMRTのみではなく, 全ての放射線 治療にとって重要である.

患者の固定精度を確保することは神経の使う現場業務で あり，もっぱら技師の技量と工夫により精度確保されては いるものの, 広くどの病院でも高精度放射線治療が可能と いうわけにはいかなかった。画像誘導放射線治療（IGRT） は，かかる困難を改善するために，放射線診断の技術を， 放射線治療の分野へ応用し, 医師や技師が治療現場で腫瘍 位置を視認しながら照射できる画期的な治療法である.

光子線治療では, リスク臓器への照射を回避できる方法 


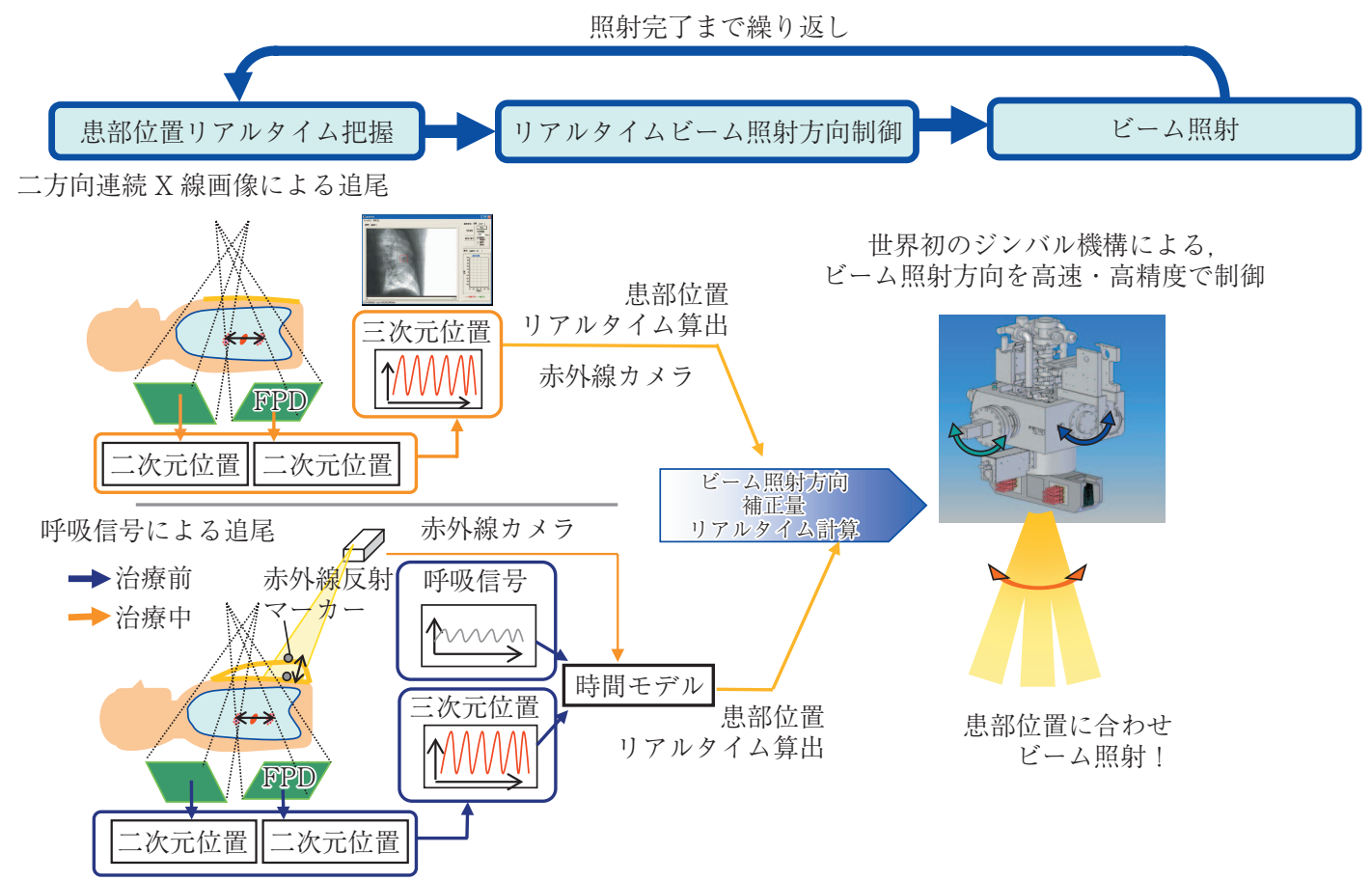

図 7 動体追尾照射の流れ

(IMRT), 腫瘍の位置を視認しながら照射する方法 (IGRT), および動体追尾照射などの考案によって, 治療 法の進展が著しい. それぞれの方法の専用機はみられた が，それらの治療を統合して実現する放射線治療機は見当 たらず，医師，技師，がん患者のニーズにタイムリに対応 できているとはいえなかった。

本稿で紹介した装置により，放射線治療の分野において 近年著しく進展した高精度な治療を, 医師, 技師, がん患 者の負担を減らし，確実にかつ安全に行えるようになるも のと考える。

\section{6. おわ に}

放射線治療は，患者個々のがん特性や時間変化に対し， よりオーダーメイド化されるなど, Adaptiveな治療へと 進化すると考えられる.

本稿で紹介した装置により, 高精度放射線照射機能と統 合された IGRT 機能をフル活用し, 患者に優しく, かつ, 病院・医師・技師にとって信頼性の高い治療装置は，わが 国の放射線治療を必要とする全てのがん患者に対して，極 めて恩恵をもたらすものと考えられる.

\section{参 考 文 献}

1) W.H. Bragg and R. Kleeman : Phil. Mag., 6, 8 (1904) 726.
2) H. Shirato, S. Shimizu, T. Kunieda, K. Kitamura, M. van Herk, K. Kageki, T. Nishioka, S. Hashimoto, K. Fujita, H. Aoyama, K. Tsuchiya, K. Kudo and K. Miyasaka : Physical Aspects of a Realtime Tumor-tracking System for Gated Radiotherapy, Int. J. Radiat. Oncol. Biol. Phys., 48 (2000) 1187-1195.

3) M.J. Murphy: Tracking Moving Organs in Real Time, Semin Radiat. Oncol. 14 (2004) 91-100.

4) Y. Kamino, et al. : Development of a Four-dimensional Imageguided Radiotherapy System with a Gimbaled X-ray Head, Int. J. Radiat. Oncol. Biol. Phys., 66 (2006) 271-278.

5) Y. Kamino, et al. : Development of a New Concept Automatic Frequency Controller for an Ultra-small C-band Linear Accelerator Guide, Med. Phys., 34 (2007) 3243-3249.

6) A. Pizkall, M.P. Carol, B. Pickett, et al. :The Effect of Beam Energy and Number of Fields on Photon-based IMRT for Deepseated Targets, Int. J. Radiat. Oncol. Biol. Phys., 53 (2002) 434442.

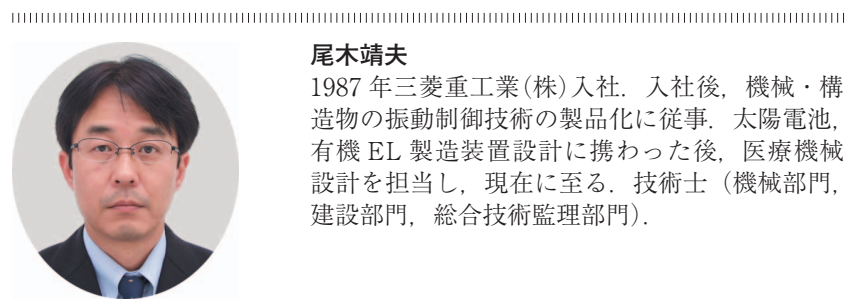

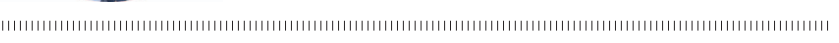

